\title{
China's Natural Forest Protection Program: Progress and impacts
}

\author{
by Hua Yang ${ }^{1}$
}

\begin{abstract}
This is a brief review on the progress and impacts of China's Natural Forest Protection Program that was initiated in response to massive flooding in 1998 of the major river basins of China. The program was heavily financed by the central government and was a success in terms of three program goals: timber harvest control in the natural forests; increase in the total area of forest protection; and, the successful resettlement of forest workers who were affected by reduced harvests. The ecological, social, and economic impacts of the program are discussed.
\end{abstract}

Keywords: natural forest protection and restoration, timber harvest control, plantations

\section{RÉSUMÉ}

Voici une brève revue des progrès et des résultats qu’a connus le Programme de protection des forêts naturelles chinoises amorcé à la suite de l'importante inondation survenue en 1988 dans les principaux bassins de rivières de la Chine. Le programme, financé à grands frais par le gouvernement central, a été couronné de succès dans les trois axes qu’on lui avait donné : contrôle de la récolte dans les forêts naturelles; augmentation de la surface forestière totale sous protection; et rétablissement des travailleurs forestiers qui avaient subi les contrecoups de la diminution de la récolte. Cet article examine les effets du programme sur les volets écologiques, sociaux et sur l'économie.

Mots-clés : protection et rétablissement des forêts naturelles, récolte de bois, plantations

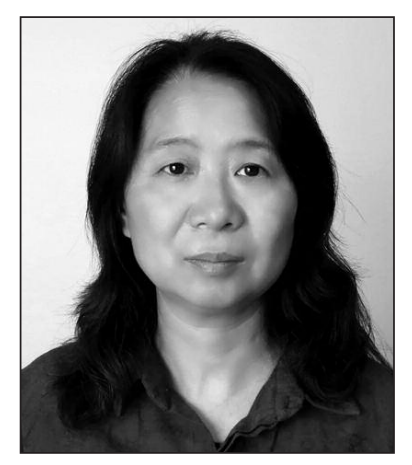

Hua Yang

\section{Program Initiation}

In 1998, massive flooding occurred in the major river basins of Yangtze, Songhua, and Nenjiang Rivers in China, causing a total loss of 166.6 billion yuan (CA \$ 33.2 billion; CA $\$ 1$. = 5.02 yuan, May 2017). Aside from heavy rains brought about by abnormal weather patterns and the malfunction of water conservancy facilities (Yang 1998), the disastrous floods were attributed also to deforestation by over-logging in the upstream regions of the river systems (Ma 2008). In response, the Chinese Government initiated the NFPP (Natural Forest Protection Program), which included logging restrictions, the establishment of protected areas and plantations, and a range of other policies aimed at controlling deterioration of the ecological environment, protecting biodiversity, and promoting social and economic sustainability (Zhang et al. 1999, 2000). In the state forests, the NFPP offers an opportunity to restore fragile systems in terms of forest cover and stocking levels and relieves forest industry from economic and social crises due to depleted resources by decades of excessive timber harvest (Zhao and Shao 2002, Xu et al. 2004).

In 2000, the NFPP was fully implemented in 17 provinces and autonomous regions after the experimentation in 12 pilot provinces from 1998 to 2000 (Zhang et al. 1999, 2000). Three program goals were identified from short- to long-term bases. The short-term goals between 1998 and 2000 were to reduce commercial logging of the natural forests by instituting a logging ban in the upper reaches of the Yangtze and in the middle and upper reaches of the Yellow River and reduce harvest levels in state forests of the Northeast and Inner Mongolia, enhance afforestation and protection in ecologically sensitive areas, and create jobs for forest workers affected by the reduction of timber harvests. By 2010, the commercial timber harvest shifted from natural forests to fast-growing, highyielding plantations, along with the further development and protection of ecological forests (forests for maintaining and improving the environment only), the recovery of natural forests for future wood supplies, and the development of nontimber forests. By 2050, natural forests will be completely recovered in terms of balanced age structure and stocking levels, wood supplies will be provided solely from plantations, and ecological and economic sustainability in the state forests will be fully achieved. Other than the three years of the experimental period, the NFPP runs by phases of every ten years.

\section{Program Progress}

Statistics from the first 19 years (experimentation stage from 1998 to 2000, phase I from 2001 to 2010, and phase II from 2011 to 2016) indicate that NFPP was a success in terms of total investment, timber production control in the natural forests, areas of forest protected, and resettlement of forest workers. Following the initial 18 billion RMB (CA $\$ 3.6$ bil-

${ }^{1}$ Faculty of Forestry, Beijing Forestry University, 35 Qinghua East Road, Haidian District, Beijing, China huayang@bjfu.edu.cn 
Table 1. Species recommended for fast-growing and high-yield timber plantations $\left[>15 \mathrm{~m}^{3} \mathrm{ha}^{-1}\right.$ year ${ }^{-1}$ ]

Industrial utilization and rotation (in brackets)

Climate zone and provinces

Tropical: Guangdong, Guangxi,

Hainan, and Fujian

Subtropical: Jiangsu, Zhejiang, Anhui, Jiangxi, Hubei, Hunan, and Yunan

Warm temperate: Hebei, Shandong, and Henan

Temperate: Heilongjiang, Jilin, Liaoning, and eastern Inner Mongolia
Wood fibre and panels Saw logs

Eucalyptus, acacias (4-7 years); Chinese red Teak, mahogany, and Himalayan birch pine, slash pine, and Caribbean pine (12-15 years)

(25-30 years)

Hybrid poplars (European and American crossings), pond cypress, Eucalyptus, and Moso bamboo (4-10 years); Chinese red pine, slash pine, loblolly pine, burma pine, and Khasi pine (12-15 years)

Triploid Chinese white poplar, hybrid poplars (European and American crossings), paulownia, and paper mulberry (3-12 years)

Native (Ussuri, Mongolian, Korean) and hybrid ("Baicheng 2") poplars (10-15 years); larch (Dahurian, Olga Bay, and Japanese) (18-20 years)
Pond cypress, Phoebe, Camphor tree, Chinese fir, and Chinese cryptomeria (25 years)

$\mathrm{n} / \mathrm{A}$
Manchurian ash, Manchurian walnut, Amur cork tree, linden, oak, Korean pine, spruce, fir, Mongolian pine, and larch (20-30 years)

Data source: State Planning Committee (2002)

lion) during the experimentation stage (Zhang 2000), the central government invested 111.9 billion RMB (CA \$ 22.3 billion) (Sun 2011), exceeding the 96.2 billion RMB (CA \$ 19.2 billion) planned for the phase I period of the NFPP. An additional 28 billion RMB (CA \$ 5.6 billion) was also allocated during phase I to help forest industry with its debt and social insurance programs in retirement, unemployment, and health care because of revenue reduction from timber harvests (Sun 2011). The total investment during phase II of the NFPP from 2011 to 2020 will increase to 244 billion RMB (CA \$ 48.6 billion). In 19 years from 1998 to 2016, about 115 million ha natural forests were protected at three levels of administration: county, forest farm, and work station, and 16.2 million ha of plantations were established, aerially seeded and closed road access for natural restoration. Harvest levels were reduced from 32 million $\mathrm{m}^{3}$ in 1997 to zero in 2016 within the NFPP area. The cumulative reduction of timber harvest in 19 years from 1998 to 2016 was 430 million $\mathrm{m}^{3}$, equivalent to a total of 740 million $\mathrm{m}^{3}$ wood consumption and 2.2 billion tonnes of carbon dioxide.

A key component of the NFPP was the development of alternative employment opportunities for forest workers affected by the reduction of harvests from the natural forests. About a million forest workers were surplused from the protection of natural forests (Zhang 2000). Among them, 650000 were retrained to work in forest protection, resource management, or silviculture including seedling production, planting, stand improvement, thinning, and infill-planting; the rest were settled with a payout sum of three times of their annual salary (Sun 2011, State Forestry Administration of China 2016a). Due to the quick growth of China's economy during this period, many displaced workers accepted non-forest employment, including construction, mining, and tourism, or they became self-employed in cultivation of non-timber forests (State Forestry Administration of China 2015). The analysis by Wang (2010) indicated that the protection of natural forests by the NFPP promoted forest tourism. As a result, the total revenue from forest parks in China increased from 6.9 billion RMB (CA \$ 1.4 billion) in 2004 to 70.6 billion RMB (CA \$ 14.1 billion) in 2015, creating nearly 300000 jobs, mostly in the natural forest areas (State Forestry Administration of China 2016a). Although income directly from logging was reduced, the overall impact of the NFPP on total household incomes in rural areas was quite positive (Mullan et al. 2010). The average annual salary in the state forest regions increased from $5200 \mathrm{RMB}$ (CA \$ 1036 ) to more than 40000 RMB (CA \$ 7968 ) in 15 years between 2001 and 2016 (China Central Television News, Feb. 18, 2017), even though the numbers are still lower than the local averages (Sun 2011).

The long-term success of the NFPP depends on the development of fast-growing and high-yielding plantations. According to the outline by the State Planning Committee (2002) for the Timber Base Development Program (TBDP) initiated in parallel to the NFPP, 13.4 million ha of commercial timber forests will be established within the key areas of industrial plantations, 4.7 million ha between 2001 and 2005, 4.5 million between 2005 and 2010, and 4.2 million between 2010 and 2015, in addition to the 5.3 million ha established previously. The plantation species are recommended according to industrial uses and climate zones of the provinces (Table 1; Fig. 1), even though the extensive use of single species plantations has been heavily criticized (Zhou and Sheng 2008). The progress has been relatively slow; only 1.7 million ha had been established by 2014 (State Forestry Administration of China 2016a), about 13\% of the target, despite more plantations of fast-growing trees during this period that are often low in growth and quality (Zhou and Sheng 2008). This has been attributed to lack of interest from 


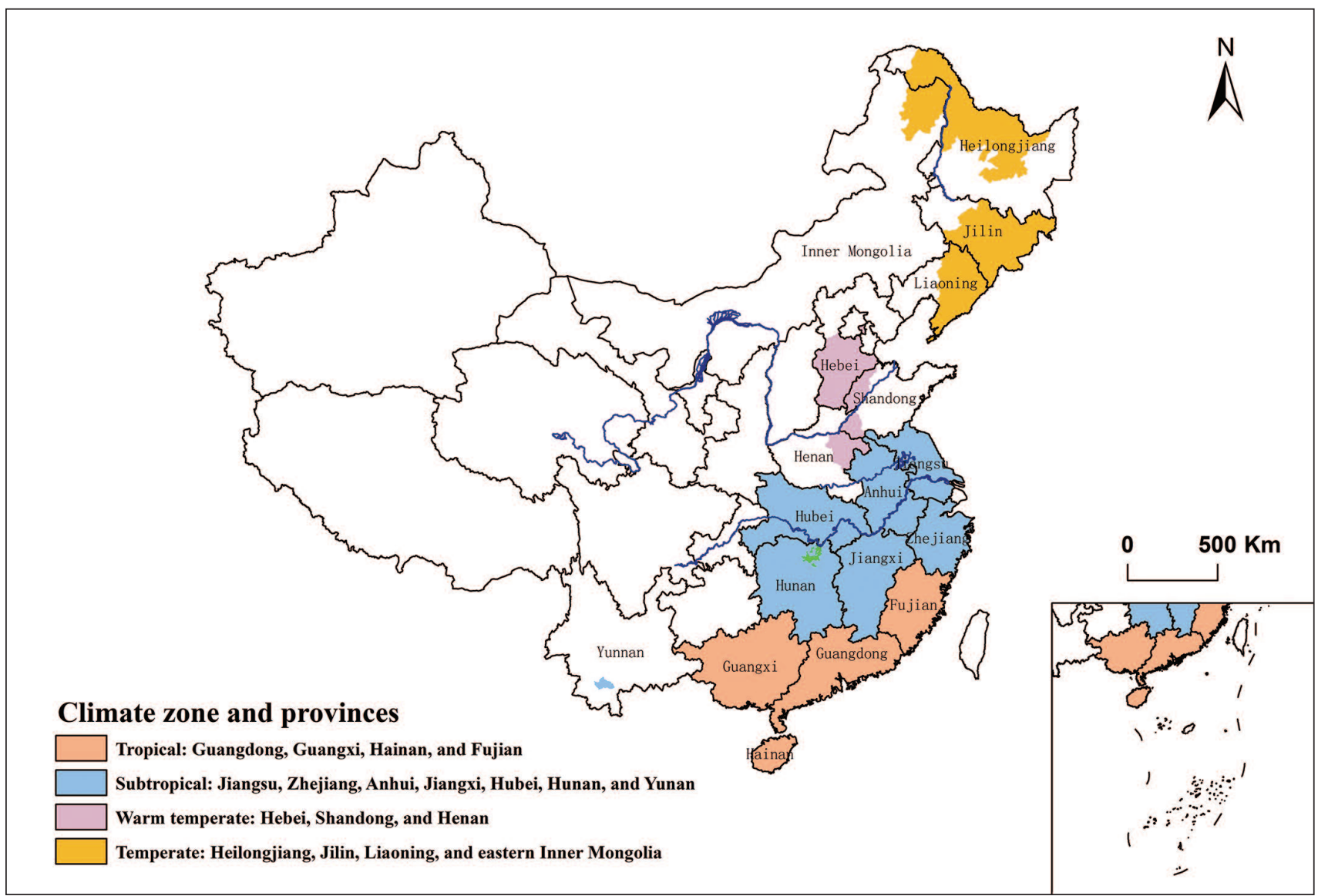

Fig. 1. Regionalization of the fast-growing and high-yield timber base development in major forest regions, China. Mean annual temperature and precipitation are above $16^{\circ} \mathrm{C}$ and $1000 \mathrm{~mm}$ in the tropical zone, $14^{\circ} \mathrm{C}$ and $800 \mathrm{~mm}$ in the subtropical zone, $11^{\circ} \mathrm{C}$ and 500 $\mathrm{mm}$ in the warm temperate zone, and $0^{\circ} \mathrm{C}$ and $500 \mathrm{~mm}$ in the temperate zone.

investors and industry and post-planting management due to uncertainty and the long-term nature of forest investments (State Planning Committee 2002). The availability of highquality lands may also restrict development of high-yield plantations (Dai et al. 2013).

\section{Program Impacts}

The logging ban in the upstream regions of the Yangtze, Songhua, and Nenjiang rivers and the state natural forests, and afforestation and protection in ecologically sensitive areas has a positive environmental impact (Ouyang et al. 2016), especially in mountainous areas, although a complete logging ban may not be the optimum solution for the sustainable management of local forests (Wang et al. 2006). According to program evaluations in the Northeastern provinces and in eastern Inner Mongolia, the total ecological benefits in soil and water conservation, carbon sequestration and oxygen production, nutrient accumulation, air quality improvement, and biodiversity conservation have increased by $637 \mathrm{RMB}$ billion/year (CA $\$ 126.9$ billion) during the implementation of the NFPP between 2001 and 2015, more than three times NFPP investments (State Forestry Administration of China 2015).
The increase of total forest stocks accelerated after the initiation of the NFPP, a possible indication of forest recovery by natural forests. National Forest Inventory data showed net increases of 15.7 million ha plantations, 3.4\% forest cover, and 2.7 billion $\mathrm{m}^{3}$ growing stock during the 10 -year period of the NFPP between the sixth (1999-2003) and the eighth (20092013) National Forest Inventories (Table 2). The incremental changes between consecutive inventories seem to become greater in growing stock, but not in total forests, total plantations or forest cover after initiation of the NFPP. Viña et al. (2016) also indicated a 1.6\% forest cover gain and Ren et al. (2015) showed a 77\% reduction in deforestation loss in the NFPP areas over the period 2000 and 2010 based on satellite images. However, the forest cover determined on satellite images reflects more tree density and therefore growing stock, not necessarily the percent forest cover that increased 3.4\% instead during the 10-year-period according to the National Forest Inventories (State Forestry Administration of China 2016b). The lack of the NFPP contribution to total forest areas, total plantations or forest cover is possibly due to the allocation of most NFPP funding to staff salaries and social programs in retirement, unemployment, and health care and little NFPP funding on afforestation and forest management 


\begin{tabular}{lcccccc}
\hline & & $\begin{array}{c}\text { Forest } \\
\text { lands } \\
\text { Imillion } \\
\text { ha) }\end{array}$ & $\begin{array}{c}\text { Forests } \\
(\mathbf{m i l l i o n} \\
\text { ha) }\end{array}$ & $\begin{array}{c}\text { Plantations } \\
(\mathbf{m i l l i o n} \\
\text { ha) }\end{array}$ & $\begin{array}{c}\text { Forest } \\
\text { cover } \\
\mathbf{( \% )}\end{array}$ & $\begin{array}{c}\text { Growing } \\
\text { stock } \\
\text { (billion } \mathbf{m}^{3} \text { ) }\end{array}$ \\
\hline $1^{\text {st }}$ & Period & & & & & \\
$2^{\text {nd }}$ & $1973-1976$ & 257.60 & 121.86 & - & 12.70 & 8.66 \\
$3^{\text {rd }}$ & $1977-1981$ & 267.13 & 115.28 & - & 12.00 & 9.03 \\
$4^{\text {th }}$ & $1984-1988$ & 267.43 & 125.65 & - & 12.98 & 9.14 \\
$5^{\text {th }}$ & $1994-1993$ & 262.89 & 133.70 & - & 13.92 & 10.14 \\
$6^{\text {th }}$ & $1999-2003$ & 263.29 & 158.94 & 47.09 & 16.55 & 11.27 \\
$7^{\text {th }}$ & $2004-2008$ & 305.90 & 174.91 & 53.65 & 18.21 & 12.46 \\
$8^{\text {th }}$ & $2009-2013$ & 312.59 & 207.69 & 61.69 & 20.36 & 13.72 \\
\hline
\end{tabular}

Data source: State Forestry Administration of China (2016b)

(Liu and Li 2013). The greater increase of growing stock in part, may be due to the reduction of harvesting from natural forests that, on average, have higher stocking densities than plantations (Dai et al. 2013) or recently-regenerated cutblocks. The NFPP may have only temporally affected domestic timber production, and has little to do with increasing wood consumption after initiation of the program (State Forestry Administration of China 2016a). Timber production decreased from the late 1990s to the early 2000s (Dai et al. 2013), likely due to the harvest reduction from state natural forests by the initiation of the NFPP. However, timber production rebounded and reached a higher level after 2007 (Dai et al. 2013, State Forestry Administration of China 2016a) to meet the wood demand that has increased from about 300 million $\mathrm{m}^{3}$ /year in 2001-05 to over 500 million $\mathrm{m}^{3} /$ year during 2010-15 (State Forestry Administration of China 2016a). There has been a growing gap between domestic timber production and total wood demand which, however, cannot be offset by the reduction of timber harvests in state natural forests. Growing wood imports (FAO 2016) will add pressure on other countries' forests, increasing legal and illegal harvesting and producing negative impacts on forest management, environment, and biodiversity (Viña et al. 2016). However, not all of the imported wood is consumed in China; significant volumes are exported as furniture and other wood products (State Forestry Administration 2016a), as seen from simultaneously increases of both imported and exported woods since the initiation of the NFPP program (FAO 2016).

Upon the completion of phase I NFPP in 2010, phase II was initiated to run from 2011 to 2020 . The total investment from the central government is twice the level of phase I, reaching 219.5 billion $\mathrm{RMB}$ (CA $\$ 43.7$ billion). An additional 24.5 billion RMB (CA $\$ 4.9$ billion) is provided by provincial governments. The harvest level in the state-owned natural forests was further reduced to 4 million $\mathrm{m}^{3}$ in 2013 and zero in 2016 (Sun 2011, Zhang 2015). The logging ban in collective natural forests will start in the current year. Over this phase II, the total area covered by the NFPP is to be expanded to include 11 counties around Danjiangko Reservoir of Hubei and Henan provinces. Another 35 thousand forest protection and management stations are expected to be established. By 2020 the total forests within the NFPP will have increased by 5.2 million ha, the growing stock by 1.1 billion $\mathrm{m}^{3}$, and carbon storage by 0.4 billion tonnes. The total area of forests pro- tected under the NFPP will have increase by 15 million ha, ecological forests by 7.7 million ha, forest tending by 17.6 million ha, and jobs in the forest sector by 650000 .

The continuation of the NFPP will generate more ecological benefits in soil and water conservation, carbon sequestration and oxygen production, nutrient accumulation, air quality improvement, and biodiversity conservation; however, the incremental gain in ecological benefits will slow down over time by the temporal dynamics of forest ecosystem services over succession (Lu et al. 2013). The complete logging ban helps the recovery of natural forests in terms of balanced age structures and stocking levels but may not be an optimum solution for the rehabilitation of desired ecosystem functions, biodiversity, and future timber reserves. These would require active management interventions (Aronson et al. 1993, Chazdon 2008) in managing stand structure and composition (Yuan et al. 2015).

\section{References}

Aronson, J., C. Floret, E. Le Floc'h, C. Ovalle and R. Pontanier. 1993. Restoration and rehabilitation of degraded ecosystems in arid and semi-arid lands. I. A view from the south. Restor. Ecol. 1(1): 8-17.

Chazdon, R.L. 2008. Beyond deforestation: Restoring forests and ecosystem services on degraded lands Science 320: 1458-1460.

Dai, L, W. Zhao, G. Shao, B.L. Lewis, D. Yu, L. Zhou and W. Zhou 2013. The progress and challenges in sustainable forestry development in China. Int. J. Sust. Dev. world 20 (5): 394-403.

FAO. 2016. FAOSTAT (Food and Agriculture Organization of the United Nations-Statistics Division), http:/faostat3.fao.org/home/ (accessed November, 2016).

Liu, D. and H. Li. 2013. Forestry interests and reform. China's Finance and Economy Press. $165 \mathrm{p}$ (in Chinese).

Lu, S., S. Li , B. Chen and S. Nie. 2013. Evaluation of forest ecosystem services and forest succession in the mountainous region of Beijing, China. J. Food Agric. Environ. 11 (3\&4): 2674-2681.

Ma, T. 2008. Interconnected Forests: Global and Domestic Impacts of China's Forestry Conservation. China Environmental Health Project Research Brief, China Environmental Health Project, United States Agency for International Development, Washington DC, 2008. Mullan K., A. Kontoleon, T.M. Swanson and S. Zhang. 2010. Evaluation of the impact of the Natural Forest Protection Program on rural household livelihoods. Environ. Manage. 45(3): 513-525.

Ouyang, Z. et al. 2016. Improvements in ecosystem services from investments in natural capital. Science 352 (6292): 1455-1459.

Ren, G., S.S. Young, L. Wang, W. Wang, Y. Long, R. Wu, J. Li, J. Zhu and D.W. Yu. 2015. Effectiveness of China's National Forest Protection Program and nature reserves. Conserv. Biol. 29(5): 1368-1377.

State Forestry Administration of China. 2015. The ecological and social impacts of the Natural Forest Protection Program in the key state forest regions of the northeastern provinces and Inner Mongolia. China Forestry Publishing House. 212 p (in Chinese).

State Forestry Administration of China. 2016a. China forestry development reports 2000-2015. Available at http://www.forestry. gov.cn/CommonAction.do? dispatch $=$ more $\&$ colid $=62 \& p=1 /$ [Accessed November 2016] (in Chinese). 
State Forestry Administration of China. 2016b. National Forest Inventories. Available from China forestry database at http:// data.forestry.gov.cn/lysjk/indexJump.do?url=view/moudle/index/ [Accessed November 2016] (in Chinese).

State Planning Committee. 2002. Approval on the program outline for fast-growing and high-yield timber base development in major forest regions. Agri. Econ. 2002-1037 (in Chinese).

Sun, G. 2011. Policy interpretations of Phase II Natural Forest Protection Program. Interviewed by China Talk on May 25, 2011. Available at http://www.china.com.cn/fangtan/2011-05/25/content_ 22640750.htm [Accessed November 2016] (in Chinese).

Viña, A., W.J. McConnell, H. Yang, Z. Xu and J. Liu. 2016. Effects of conservation policy on China's forest recovery. Sci. Adv. 2 (3): e1500965.

Wang, Q., X. Ruan, C.-D. Pan, N.-Y. Xu, X. Luo and M.-M. Huang. 2006. Need for sustainability policy - a case study of the Natural Forest Conservation Program (NFCP) in the western region of Tianshan Mountain, China. For. Chron. 82(1): 31-39.

Wang, Y. 2010. Social impact assessment of the Natural Forest Protection Program on the forest-dependent communities and households in Western China - Case studies in Gansu Province and Chongqing Municipality. Ph.D. Dissertation. Technische Universität Dresden, Germany. 244 p.
Xu, J., R. Tao and G.S. Amacher. 2004. An empirical analysis of China's state-owned forests. For. Policy Econ. 6(3-4): 379-390.

Yang, M. 1998. An analysis on the flood of the Changjing River in 1998. Sci. Technol. Rev. 10: 3-6 (in Chinese).

Yuan, S.Q., Q.Y. Shen, J. Tian and X.H. Bai. 2015. Research report of the full stop forest commercial cutting in Heilongjiang forest area. For. Econ. 2: 47-51(in Chinese).

Zhao, G. and G. Shao. 2002. Logging restrictions in China: A turning point for forest sustainability. J. For. 100(4): 34-37.

Zhang, P., G. Shao, G. Zhao, D.C. Le Master, G.R. Parker, J.B. Dunning and Q. Li. 2000. China's forest policy for the 21st century. Science 288 (5474): 2135-2136.

Zhang, P., X. Zhou and F. Wang. 1999. Introduction to Natural Forest Conservation Program. China's Forestry Publishing House, Beijing (in Chinese).

Zhang, Y. 2015. The 2020 goal of the Natural Forest Protection Program. Available at http://www.gov.cn/xinwen/2015-12/03/content_ 5019326.htm/ [Accessed November 2016] (in Chinese).

Zhou, T. and W. Sheng. 2008. On the plantation sustainability in China. World For. Res. 21: 49-53 (in Chinese). 